\title{
An overview of impact of subsurface drainage project studies on salinity management in developing countries
}

\author{
Priyanka Tiwari $^{1} \cdot$ Arun Goel $^{1}$
}

Received: 29 December 2014/ Accepted: 25 August 2015/Published online: 22 September 2015

(C) The Author(s) 2015. This article is published with open access at Springerlink.com

\begin{abstract}
Subsurface drainage has been used for more than a century to keep water table at a desired level of salinity and waterlogging control. This paper has been focused on the impact assessment of pilot studies in India and some other countries from 1969 to 2014. This review article may prove quite useful in deciding the installation of subsurface drainage project depending on main design parameters, such as drain depth and drain spacing, installation area and type of used outlet. A number of pilot studies have been taken up in past to solve the problems of soil salinity and waterlogging in India. The general guidelines that arise on the behalf of this review paper are to adapt drain depth $>1.2 \mathrm{~m}$ and spacing depending on soil texture classification, i.e., $100-150 \mathrm{~m}$ for light-textured soils, 50-100 m for medium-textured soils and 30-50 m heavy-textured soils, for better result obtained from the problem areas in Indian soil and climatic conditions. An attempt has been made in the manner of literature survey to highlight the salient features of these studies, and it is hopeful to go a long way in selecting design parameters for subsurface drainage problems in the future with similar soil, water table and climatic conditions.
\end{abstract}

Keywords Subsurface drainage $\cdot$ Salinity $\cdot$ Waterlogging and groundwater table

Priyanka Tiwari

tiwari.priyankatiwari.p2@gmail.com

Arun Goel

drarun_goel@yahoo.co.in

1 Department of Civil Engineering, National Institute of Technology (Institute of National Importance), Kurukshetra, Haryana 136119, India

\section{Introduction}

Land and water are two basic natural resources. Due to rapid population growth and fast industrialization, these resources are facing immense pressure and are depleting day by day. According to the FAO land and plant nutrition management service (1994), over $6 \%$ of the world's land is affected by either salinity or sodicity. Much of the world's land is not cultivated; however, a significant proportion of cultivated land is salt-affected, and of the current 230 million ha of irrigated land, 45 million ha is salt-affected $(19.5 \%)$, and of the 1500 million ha under dry land agriculture, 32 million ha is salt-affected to varying degrees, i.e., $2.1 \%$ (Hefny et al. 2013). World's large irrigated regions with serious salinity problems are Yellow River Plain in China, San Joaquin Valley in California, KaraKum Canal project in Turkmenistan, Indus Plain in Pakistan, Tigris-Euphrates Plain in Iraq, Murray-Murrumbidgee Area in Australia and lower Nile Valley in Egypt, which need a serious attention of researchers (Ghassemi et al. 1995).

Subsurface drainage is considered as a most suitable approach for groundwater balance and land and water management practices containing the groundwater table at a suitable level (Luthin 1978; Gates and Grismer 1989). Agricultural subsurface drainage is a process of removal of excess groundwater from the crop root zone system which promotes safe environment for efficient crop growth and for better health in rural and urban areas. Subsurface drainage lowers the high water tables, and the main causes of the rise in water table are precipitation, excess irrigation, leaching water, seeps from higher land or irrigation canal and ditches and groundwater under artesian pressure. This technique has gained international acceptance. Subsurface agricultural drainage provides agronomical and 
environmental benefits in terms of improved crop yield, improved soil trafficability, field operations and reduction in sediment and phosphorus losses from agricultural fields (Kornecki et al. 2001).

Subsurface drainage has been found to be the only solution for providing land reclamation on a long-term basis when salts are present in the soil and groundwater. Subsurface drainage has been provided in $75-80 \%$ of irrigated area in Egypt and 25-30\% irrigated area in western USA Goel and Tiwari (2013). Comprehensive reclamation programs involving provision of subsurface drainage in irrigated areas have been embarked in a big way in Pakistan over the past 50 years, while these started much earlier in India during late 1920s (Thatte and Kulkarni 2000), and FAO (1999) reported that India has 2.5 million ha waterlogged land and 3.1 million ha salinity-affected area, while this hazard on the state level in India is extended, i.e., Uttar Pradesh has salinity-affected area over 1 million hectares, 1 million hectares in Gujarat, 0.5 million ha in Punjab, 0.2 million ha in Haryana and a smaller area in Rajasthan, and significant less proportionate area in Tamil Nadu in the south is also affected. At the time of nineties, subsurface drainage installed $<10 \%$ of the total irrigated area Zimmer et al. (2002). But currently $<0.02 \%$ irrigated area in India is provided with subsurface drainage Tiwari (2011), and Maharashtra state has minimum salt-affected area to the extent of $0.6 \mathrm{M}$ ha (Sethi et al. 2010).Still India is facing varying degree of salinity problems such as saline soil, costal saline and alkalinity (Patel et al. 2002; Mandal and Sharma 2011).

Some past review papers and past remarkable studies on subsurface drainage and salinity management were discussed in this session. The purpose of this literature survey is that the findings and recommendations of these studies would be useful to take as guidelines to plan a new subsurface drainage system in an efficient, effective, economic and ecofriendly manner for future in India and other countries.

Gupta $(2002$, 2003) has summarized past 100-year Indian efforts to control salinity and waterlogging problems, which were conducted under the supervision of Central Soil Salinity Research Institute (CSSRI) from 1972 to 2002 . He has covered several pre- and post-independence pilot studies and their salient findings from 1873 to 1975. He has provided general drainage design guidelines and operationalizes the subsurface drainage system for Indian conditions.

Kaledhonkar et al. (2009) have summarized preliminary studies conducted in India from 1980 to 2008 . He has been enlightening on the 18 Haryana, 3 Gujarat, 2 Maharashtra, 2 Andhra Pradesh, 1 Karnataka and 1 Rajasthan pilot studies of their saline areas in the listed states, and he made efforts to focus the subsurface drainage operational and subsurface drainage effluent management problems. They discussed the drainage design parameters, crop production, cropping intensity and cost investment for the subsurface drainage installations but did not considered the maintenance of SSD.

Several researchers have suggested different strategies for salinity management in developing countries from 1969 to 2014. Special issues in SSD are discussed/highlighted, and specific methodologies for design of SSD are summarized in this paper. In the end, some of the general guidelines have been proposed which can be kept in mind while designing any SSD project in future.

\section{Subsurface drainage pilot or project studies}

\section{India}

The requirement of salinity management was firstly reported by Punjab Govt. in 1865 to Governor General. Mr. Robertson and started India's first drainage project in 1873 to reclaim the land from waterlogging, and people cure from malaria disease. History of northwest India's salinity has to reclaim through subsurface drainage installation and keep functioning it till achieving the aim of installation (Hanumanthaiah and Satyanarayana 2003). But they always worried about drain discharge disposal. Till few years ago, the drain discharge was disposed in canals. And also they tried to reuse the saline drain water in crop production, but the problem in those days was the pumping out of large quantity of drain discharge. So nowadays, the drainage installation is costly and seen more problematic in disposal point of view. A number of pilot scales subsurface drainage projects undertaken by CSSRI Karnal (Haryana), India, during 1980s have slowly paved the way for communication of large-scale mechanically installed drainage projects in Haryana, Rajasthan, Gujarat, Punjab, Andhra Pradesh, Maharashtra and Karnataka. India is divided into ten climatic zones which played very important role in SSD installation because any region is more affected by their weather conditions. On the basis of the climatic zones, experimental sites are through the India map (Fig. 1).

About 35,000 ha waterlogged saline soils have been reclaimed in these states with significant improvement in crop intensity, yield, land value and farmers income. India's major pilot studies literature survey has been discussed in Table 1. Here we are discussing the important factor of the drainage design criteria with their major outcomes. The following table (Table 1) have described about India's 56 successful pilot studies with their study area, installation year, operational duration, necessary drainage design parameters and their major conclusions.

On the basis of the Table 1, the pilot studies following guidelines are framed which would be helpful in drainage 
Fig. 1 Climatic zone wise distribution of SSD studies in India

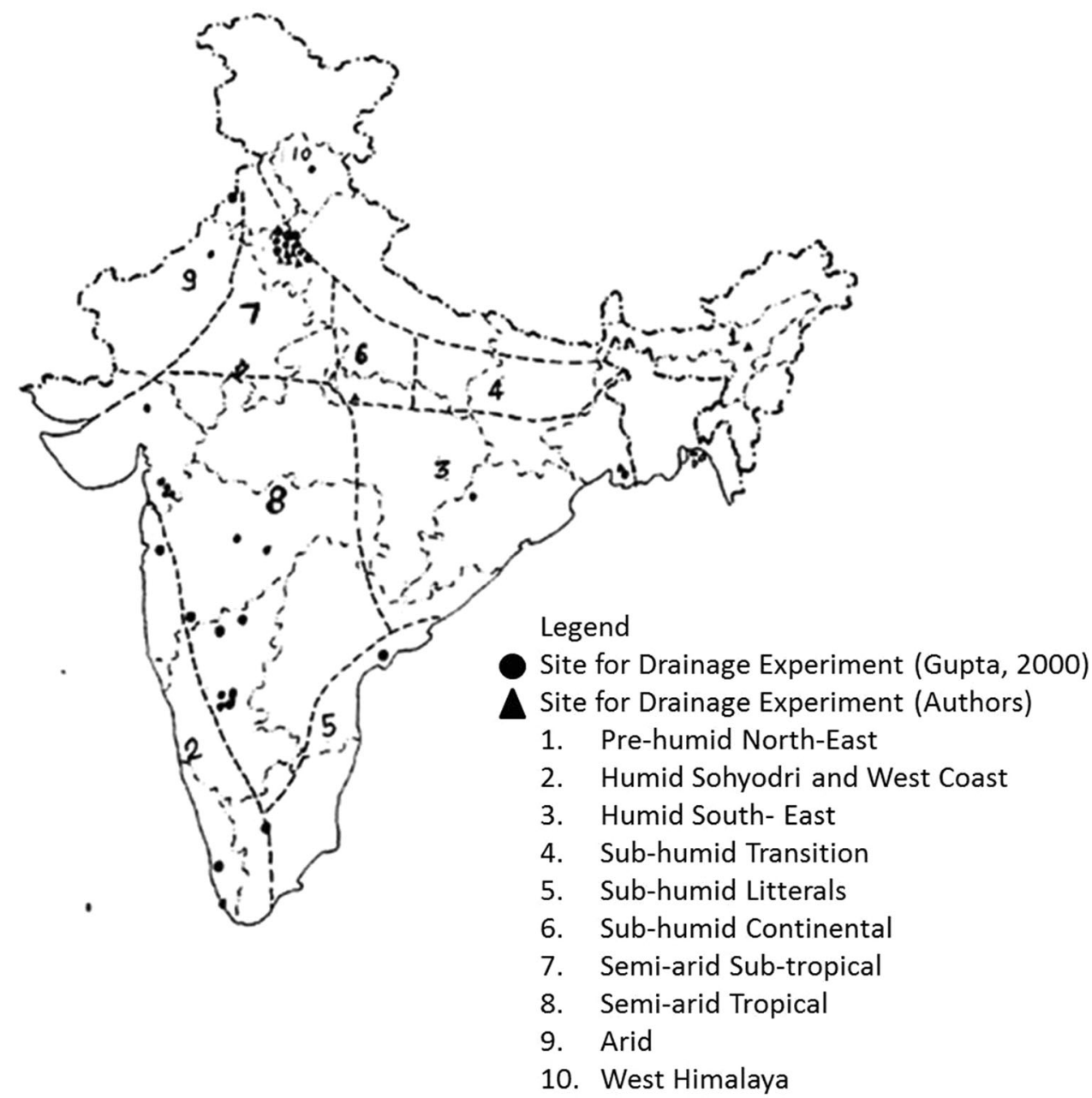

design subsurface drainage system in India. It is expected that these salient points would be useful in new wherein similar soil, water table and climatic conditions existing in India.

\section{Basic guidelines for Indian subsurface drainage design}

Although Drainage manual (1978) and Drainage design factors (1986) have recommended general guidelines for installation procedure and drainage design parameters for more effective performance yet on the basis of pilot studies undertaken in the past 50 years in India, few more guidelines have emerged which are mentioned below.

1. Before subjecting any drainage project into a problematic area, the primary data (technical, socioeconomic, geo-hydrological climate) and secondary (water quality) have to be collected, which are relevant to the particular area.

2. In past, cement concrete pipes were very popular in alkaline and saline areas because these pipes have not given any complaints up to 20 years in alkaline areas and 8 years in saline zones after installation. But nowadays PVC pipes are more popular than others due to its portability and light in weight.

3. Drainage depth is an issue of increase or decrease in cost of installation and also availability of machineries and labor. But it is depending on position of groundwater table, soil type and hydraulic characteristics. For agricultural drainage, recommended depth of the lateral is $>1.2 \mathrm{~m}$ because agricultural activities may damage the laterals.

4. Drain spacing is classified on the basis of the texture of the soil. The lateral spacing, size and grade (in \%) for light-textured soils are ranging between 100 and $150 \mathrm{~m}, 100 \mathrm{~mm}$ and $0.10 \%$, respectively, 50 and $100 \mathrm{~m}, 125 \mathrm{~mm}$ and $0.075 \%$ for medium-textured soil and 30 and $50 \mathrm{~m}, 150 \mathrm{~mm}$ and $0.05 \%$ for heavytextured soils.

5. On the basis of climatic conditions, drainage coefficient has an optimum value which lies between 1 and $3 \mathrm{~mm} /$ day (i.e., arid region is a $1 \mathrm{~mm} /$ day, semiarid region is a $2 \mathrm{~mm} / \mathrm{day}$, and subhumid region is $3 \mathrm{~mm} /$ day). 


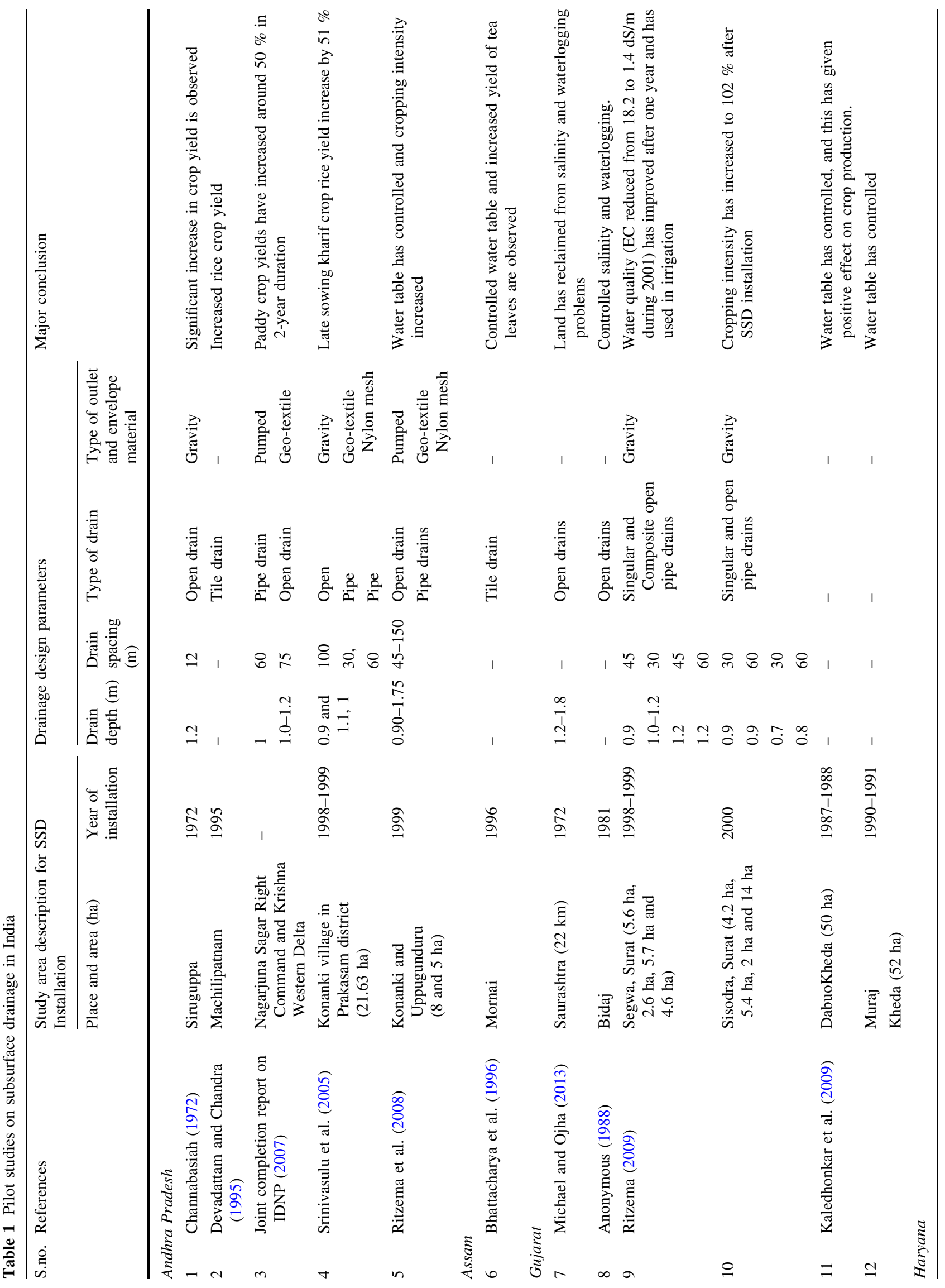




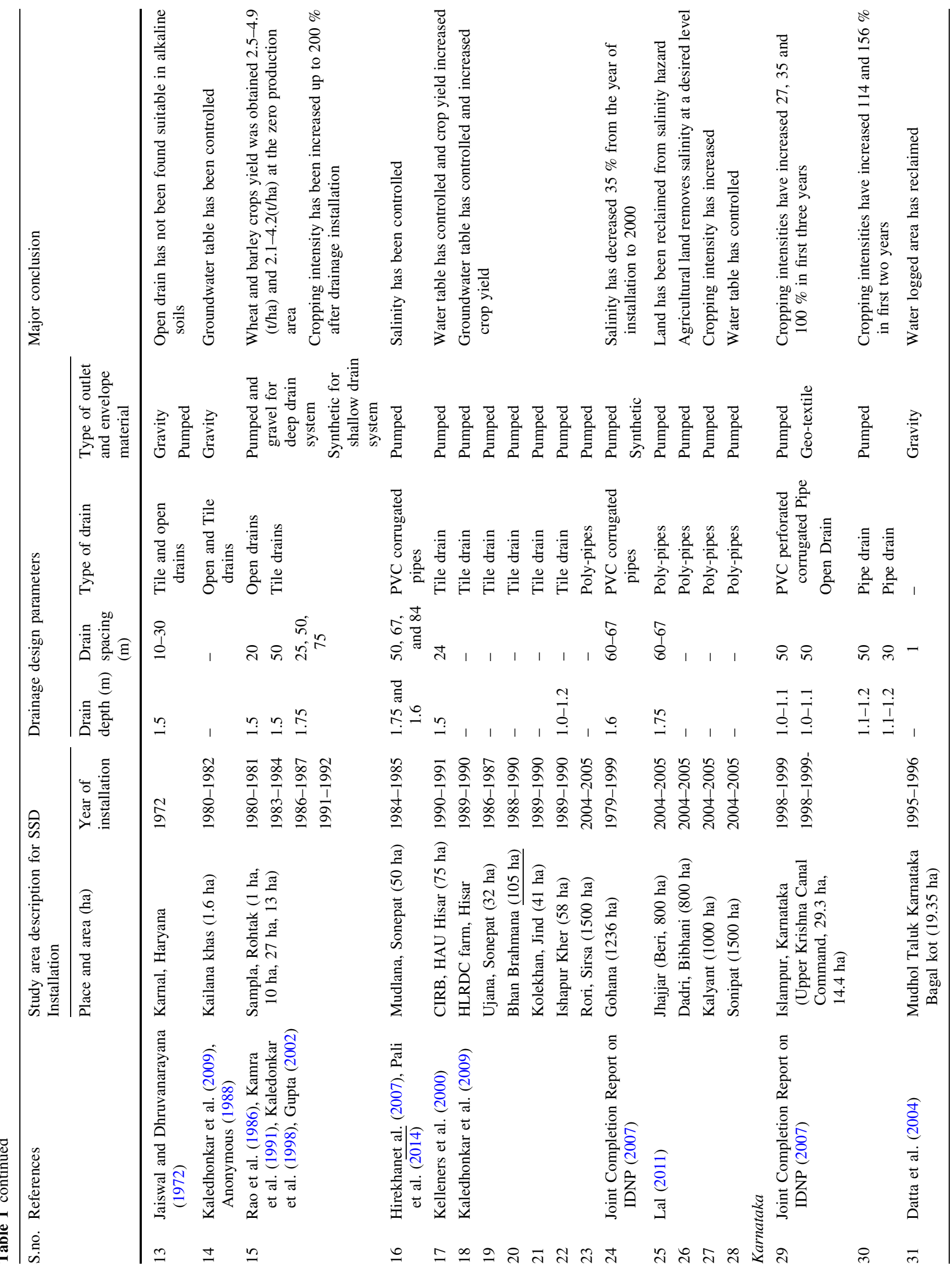




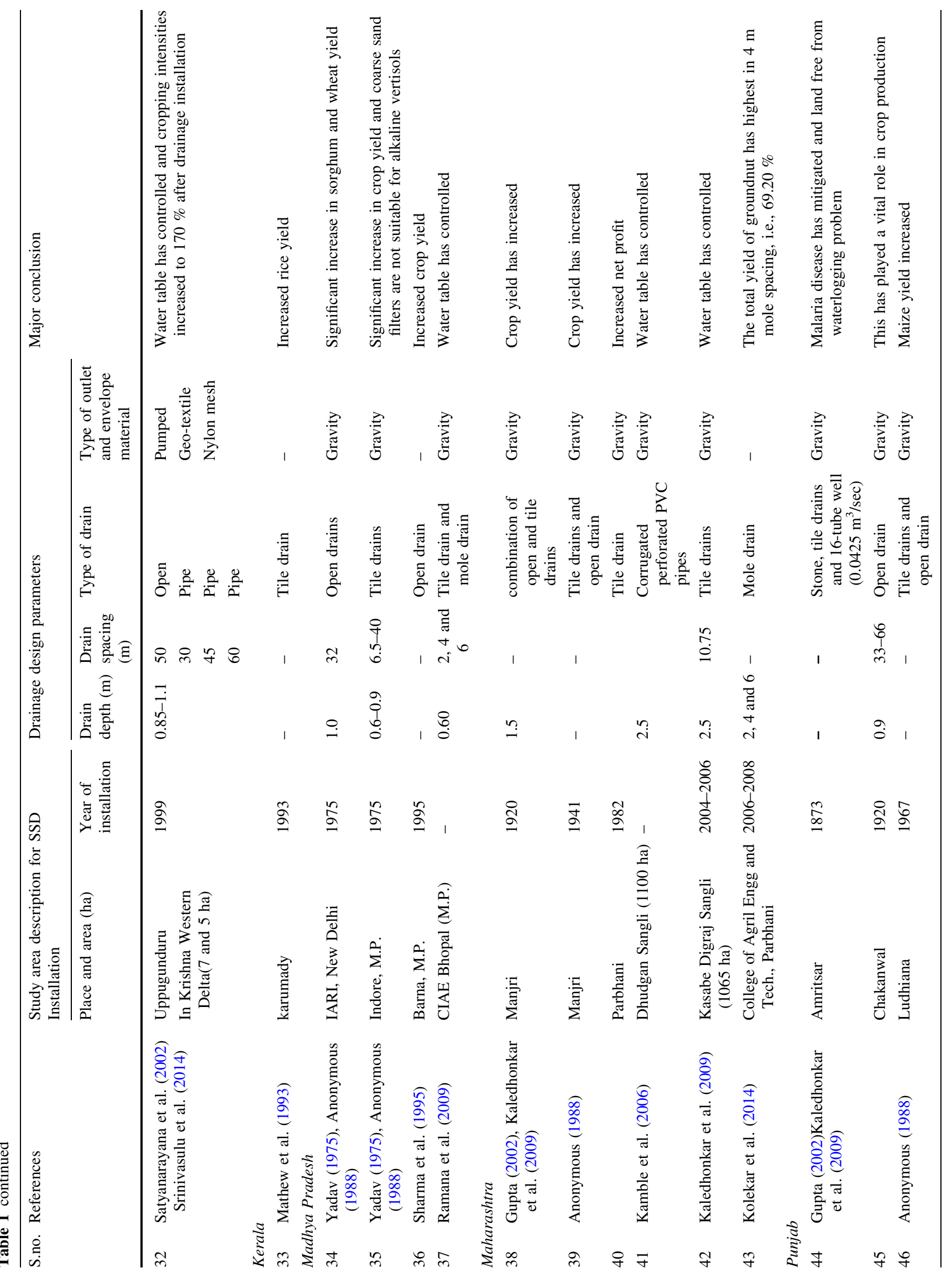




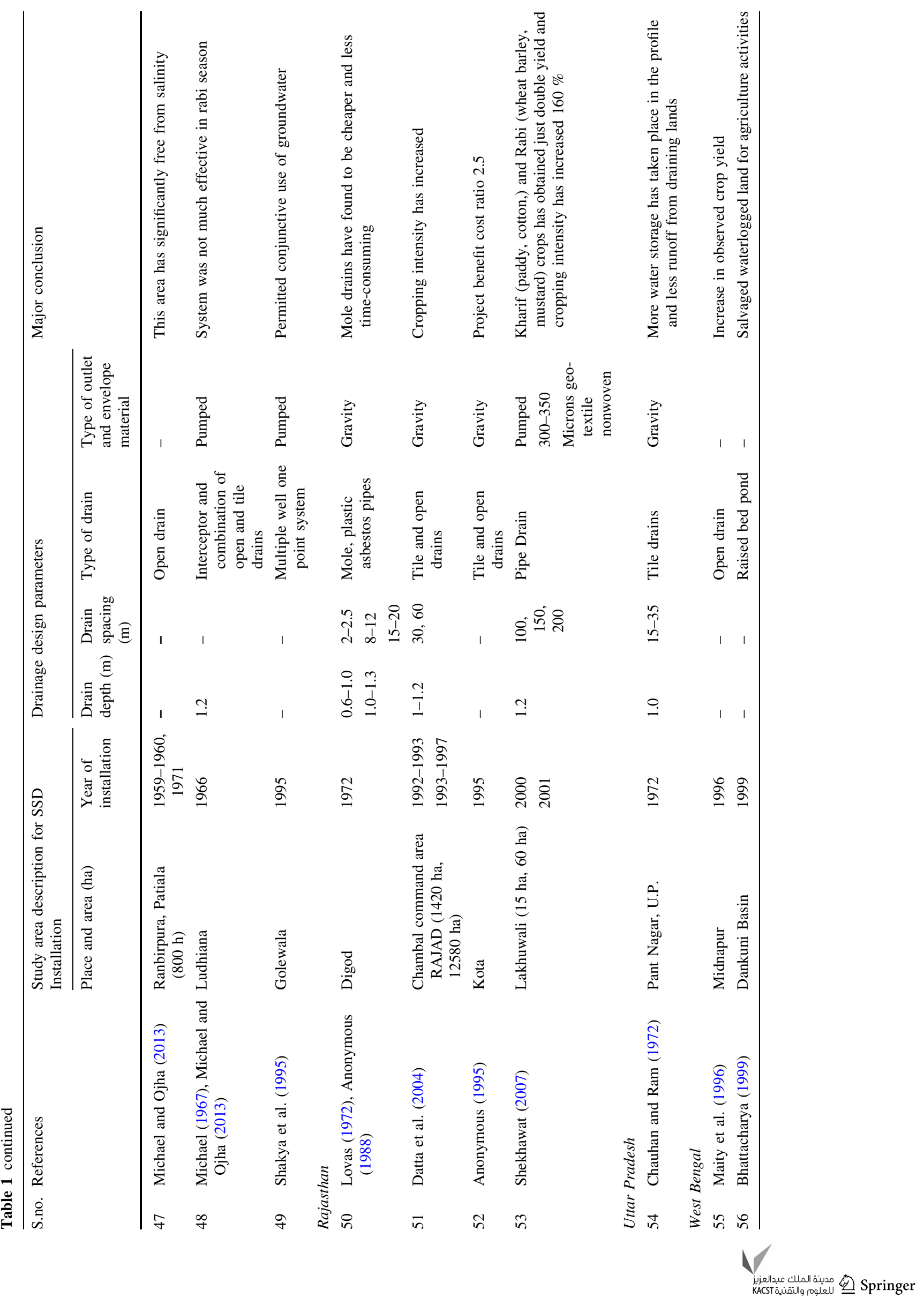




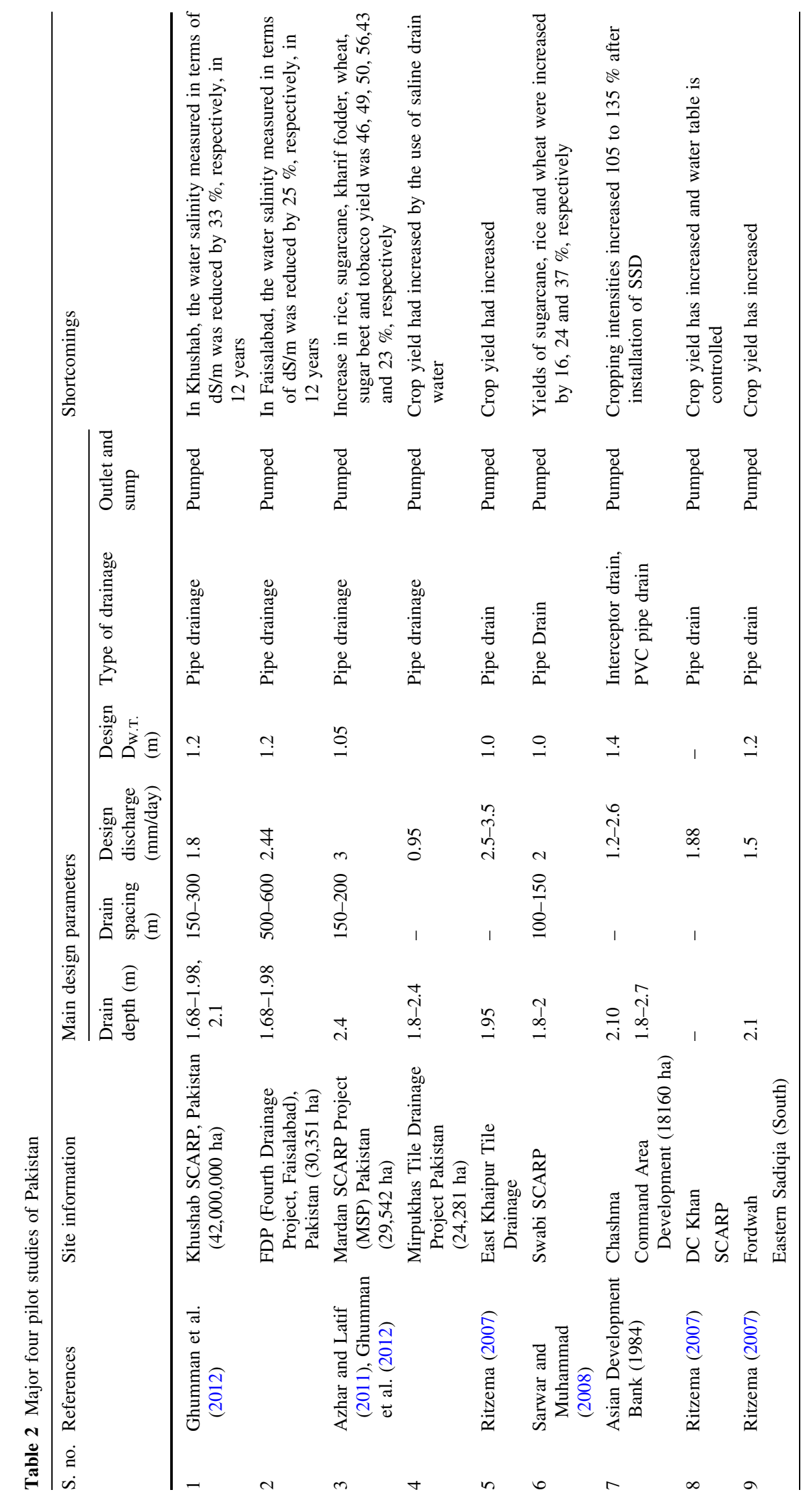


Table 3 Pilot studies on desalinization and waterlogging

\begin{tabular}{|c|c|c|c|c|c|c|c|}
\hline \multirow{2}{*}{$\begin{array}{l}\text { S. no. } \\
1\end{array}$} & \multirow{2}{*}{$\begin{array}{l}\text { References } \\
\text { Kale } 2011\end{array}$} & \multirow{2}{*}{$\begin{array}{l}\text { Location states and } \\
\text { countries } \\
\begin{array}{l}\text { Konya-C, umra Plain, } \\
\text { Turkey }\end{array}\end{array}$} & \multicolumn{2}{|c|}{$\begin{array}{l}\text { Spacing }(\mathrm{m}) \text { and } \\
\text { depth }(\mathrm{m})\end{array}$} & \multicolumn{2}{|c|}{$\begin{array}{l}\text { Type of drains and } \\
\text { type of outlet }\end{array}$} & \multirow{2}{*}{$\begin{array}{l}\text { Major conclusions } \\
\begin{array}{l}\text { Water table, soil salinity have been controlled, } \\
\text { and wheat crop yield also increased }\end{array}\end{array}$} \\
\hline & & & - & - & - & Pumped & \\
\hline 2. & Ozturk (2004) & Anatolia, Turkey & 21.3 & $1.8-2.0$ & $\begin{array}{l}\text { Tile } \\
\text { drains }\end{array}$ & Gravity & $\begin{array}{l}\text { Crop yield increased, and water table has been } \\
\text { controlled }\end{array}$ \\
\hline 3. & $\begin{array}{l}\text { El-Mowelhi et al. } \\
\text { (1988) }\end{array}$ & Nile Delta Egypt & 20,75 & 1.5 & $\begin{array}{l}\text { Tile } \\
\text { drains }\end{array}$ & Gravity & Crop yield increased \\
\hline
\end{tabular}

6. Continuous movement of water in the pipe and aquifer system collects sediment in the pipes which may affect the performance of the drainage system. For resolving the problem, the provision of filters and envelopes on the drain pipes has to be adopted. Filter/envelope material is used to filter that surrounds drain pipe, and these are commonly used along with drain pipes (geotextile, polypropylene, coconut fiber, polystyrene and foam plastic). The traditional filter material is a combination of gravel and coarse sand.

7. Normally the drain effluent is disposed in the canal, salt-making ponds, fishpond, or it can be reused in crop production. The several methods have been suggested by researchers for effluent reuse in irrigation such as blending and mixing.

\section{Subsurface drainage pilot studies in Pakistan}

As a consequence, waterlogging and salinity now are serious threats to irrigated agriculture of the 16.7 million hectare in the Indus Basin; about 2 million hectare is waterlogged, and 6 million hectare is salt-affected (Nijland et al. 2005).

Pakistan made an effort for salinity control by starting a series of salinity control and reclamation projects in 1959 , and results show a very good agreement to reduce salinity level in the surface and soil profile salinity. The salinity in percentage has been compared for 17-year variation (between the initial salinity year 1960 and 1977-1979) after installation of drainage, and this is also indicated that the salt-free areas increased up to $20 \%$ in surface and profile salinity from past decades (Bhutta 2007).

The subsurface drainage installations in Pakistan are still $<1 \%$ of the total cultivable commanded areas so it needs to be increased (Ghumman et al. 2012; Azhar et al. 2004). Bhutta (2007) has discussed salient findings of drainage research and its benefits in Pakistan. Pakistan has world's largest irrigation system, namely the Indus Basin Irrigation System that commands about $14.2 \mathrm{M}$ ha canal irrigated area (Niazi 2008). Due to poor maintenance and neglecting behavior of academician of Pakistan, most of the parts of canal are still unlined and result in the basic cause of waterlogging problem, which directly covered major part of agricultural lands of Pakistan. Niazi (2008) and Ghumman et al. (2010) reported that Government of Pakistan has made effort to save major fertile land of agriculture by the installation of major subsurface drainage projects from past few decades. Various methodologies have been used to protect agricultural lands of Pakistan from the salinity, but most of the subsurface drainage project had not proved informative and beneficial to solve the problem (Smedema 1990; Sarwar 2000; Kahlown and Khan 2004). So many approaches like surface drainage, subsurface pipe drainage and tube wells had been installed for reclamations of fertile lands of Pakistan, but subsurface pipe drainage was proved more beneficial than other two methods (Azhar et al. 2010). Four decades ago, Pakistan government was more concerned about the protection of the productive agricultural lands, and they passed eight subsurface pipe drain projects, but Sarwar and Feddes (2000) and Azhar et al. (2004) have reported that the installed drainage projects had not proved beneficial as per the expectation because these projects have not been technically sound and designed in that particular decade. After that Pakistan's irrigation and drainage engineers and scientists continuously worked on the drainage design parameters such as drainage coefficient, drain spacing Naz et al.2009) and drain depth. Kahlown et al. (2007) and Azhar and Latif (2011)have been worked on three experimental sites NIA, Bughio and Nawazabad farms in Pakistan in order to find the drainage coefficient for the efficient performance of futuristic projects and problems. History of Pakistan's irrigation and drainage researches are mainly explained by existence of nine different subsurface drainage projects (Azhar et al. 2005) as presented in Table 2.

\section{Pakistan drainage design guideline}

In Pakistan, in drained areas where a deep water table is maintained, farmers sometimes complain about the increased need of irrigation water (Qureshi et al. 1997). A shallow water table, especially in the fine soils of the Indus plains, is capable of water delivery to the crops through 
capillary rise. In areas with an 'acceptable' groundwater quality, there is no need to maintain a deep water table. The following guideline arises from the studies of the different research works. On the bases of the pilot studies, following steps are recommended.

1. In Pakistan, drainage design depth of the subsurface drainage systems should be in between 1.8 and $2.4 \mathrm{~m}$ while collector depth $>3 \mathrm{~m}$.

2. SSD drain discharge has to be designed as 0.95-3.5 mm/day.

3. PVC pipes are generally popular in field drains with fixed dimensions, i.e., diameters $100-200 \mathrm{~mm}$ and length up to $800 \mathrm{~m}$.

4. In collector drains, PVC and PE pipes are used with fixed dimensions of $200-380 \mathrm{~mm}$ in diameter and length $>4 \mathrm{~km}$.

5. Gravel filters are more popular in Pakistan subsurface drainage installation.

(C) Iraq and Egypt

In Iraq, for example, more than $50 \%$ of the lower Rafidain Plains faces a stern salinity and waterlogging problems (El-Hinnawi 1993). Similarly, salinity and waterlogging have been an inevitable problem in Egypt. These problems have existed during the pre- and postAswan High Dam periods (Ritzema 2009; IPTRID Secretariat 2007). To overcome this twin problem, subsurface drainage projects were commissioned in 1942. About $55 \%$ of agricultural land was reported as saline in Iran (FAO 1994). Waterlogging and drainage problems occur in the central and southern parts of the Saudi Arabia. In some projects, like Al-Hassa irrigation project, the agricultural drainage water is mixed with fresh groundwater and reused for irrigation. So, due to the poor quality of irrigation water, soil salinity problem is increasing (AQUASTAT 2008). Multi-level subsurface drainage has also proved beneficial (Hornbuckle et al. 2012). Hirekhan et al. (2007) have suggested that field observation must be taken before and after the installations of SSD in a semiarid climate area and have stressed on rigorous analysis before adopting a subsurface drainage technique. Chahar and Vadodaria (2010) and Chahar and Vadodaria (2012) investigated the optimal spacing in an array of fully penetrating ditches for subsurface drainage. They developed an explicit equation for computing the optimal spacing between the ditches. Eldeiry and Garcia (2010) have compared ordinary kriging, regression kriging and co-kriging techniques to estimate the soil salinity using various images. The best combinations have evaluated to estimate soil salinity with different crop types. Gammal El and Ali (2010) reported that subsurface drainage water has proved very beneficial for crop production in Egypt. Salinity and waterlogging problems affected countries are trying to reclaim their waste land, which are severely affected from these hazardous reasons presented in Table 3.

\section{Conclusions}

This paper briefly discussed the old to current state of art in subsurface drainage system, positive effects of drainage on crop production and also what the future hold for this technical approach. Pilot studies reviewed subsurface drainage investigations from 1969 to 2014 (India and abroad) with their outcomes. This study is to suggest the numeric value of drain depth which is kept greater than $1.2 \mathrm{~m}$, i.e., $>1.2-1.8 \mathrm{~m}$ and drain spacing depending on the soil texture classification, i.e., $100-150 \mathrm{~m}$ for light-textured soils, 50-100 m for medium-textured soils and 30-50 m for heavy-textured soils for Indian subsurface drainage installation in the problem area, and Pakistan subsurface drainage project studies show drain depth kept more than $1.8 \mathrm{~m}$. With the help of this paper, researchers will be able to decide the drain depth, spacing, types of subsurface drainage and type of outlets.

Open Access This article is distributed under the terms of the Creative Commons Attribution 4.0 International License (http:// creativecommons.org/licenses/by/4.0/), which permits unrestricted use, distribution, and reproduction in any medium, provided you give appropriate credit to the original author(s) and the source, provide a link to the Creative Commons license, and indicate if changes were made.

\section{References}

Anonymous (1988) Handbook for drainage of irrigated areas in India. Irrigation Management and Training Project: technical report no. 5. LBII/WAPCOS, Room 213, Ansal Chambers, Bhikaji Cama Place, New Delhi, pp 12.3 \& 12.5

Anonymous (1995) Analysis of subsurface drainage design criteria. Rajasthan Agricultural Drainage Research Project, Chambal Command Area Development, Kota, Rajasthan, pp 7.3

AQUASTAT (2008). Irrigation in the Middle East Regionc in figures. Water Report No 34, FAO. Rome, Italy

Azhar AH, Latif M (2011) Subsurface drainage impact assessment on crop yield. J Anim Plant Sci 21(2):215-219

Azhar AH, Alam MM, Rafiq M (2004). Impact of subsurface drainage systems on land and water conditions. IWASRI Publication 261, WAPDA, Lahore

Azhar AH, Alam MM, Rafiq M (2005) Agricultural impact assessment of sub-surface drainage projects in Pakistan - crop yield analysis. Pak J Water Resour 9(1):1-8

Azhar AH, Bhutt MN, Latif M (2010) Reclamation irrigated agriculture through tile drainage at Fourth Drainage Project, Faisalabad. J Anim Plant Sci 20(3):211-216

Bhattacharya AK (1999) Drainage of agricultural lands. In: Singh GB, Sharma BR (eds) 50 Years of natural resource management research. Division of Natural Resource Management, ICAR, New Delhi, pp 347-362 
Bhattacharya AK, Ray SB, Sinha AK, Ghosh G (1996) Drainage in tea plantation. AICRP on Agricultural Drainage, Water Technology Centre, IARI, New Delhi, vol 23, p 4

Bhutta MN (2007) Salient findings of drainage research and its benefits in Pakistan. Pak J Water Resour 11(1):31-38

Chahar BR, Vadodaria GP (2010) Optimal spacing in an array of fully penetrating ditches for subsurface. J Irrig Drain Eng ASCE 136(1):63-67

Chahar BR, Vadodaria GP (2012) Steady subsurface drainage of ponded surface by an array of parallel ditches. J Hydrol Eng 17:895-908

Channabasiah HSM (1972) Sub-surface drainage in salt affected medium to deep black soils in India. Lecture delivered at the Summer Institute on Saline and Alkali Soils and their Management at C.S.S.R.I., Karnal, India

Chauhan HS, Ram S (1972) Surface and sub-surface drainage hydrology. In: Proceedings symposium on waterlogging causes and measures for its prevention. CBIP. Publication, vol 118(1), pp 19-20

Datta KK, Tewari L, Joshi PK (2004) Impact of subsurface drainage on improvement of crop production and farm income in northwest India. Irrig Drain Syst 18:43-55

Devadattam DSK, Chandra RS (1995) Agricultural land drainage in coastal saline soils. AICRP on agricultural drainage, A.N.G. Ranga Agricultural University, Hyderabad, $40 \mathrm{p}$

Drainage Design Factors (1986) Irrigation and drainage. Paper no. 38. Food and Agriculture Organization of the United Nations, Rome, Italy

Drainage manual (1978) U.S. Department of the Interior, Bureau of Reclamation. U.S. Government Printing Office, Washington, DC

Eldeiry AA, Garcia LA (2010) Comparison of ordinary kriging, regression kriging, and cokriging techniques to estimate soil salinity using LANDSAT images. J Irrig Drain Eng ASCE 136(6):355-364

El-Hinnawi E (1993) Population, environment, and development in the Arab World. Paper presented to the Arab Population Conference, Amman, United Nations Economic and Social Commission for Western Asia (ESCWA)

El-Mowelhi N, El-Bershamgy A, Hoffman GJ, Chang AC (1988) Enhancement of crop yields from subsurface drains with various envelopes. Agric Water Manag 15(2):131-140

FAO (1994) Land degradation in south Asia: its severity, causes and effects upon the people. Food and Agriculture Organization of The United Nations, World Soil Resources Reports, Rome

Gammal EL HAA, Ali HMM (2010) Commissioning of abandoned drainage water reuse systems in Egypt: a case study of upgrading the Umoum project, Nile Delta. Irrig Drain 60(1)115-122

Gates TK, Grismer ME (1989) Irrigation and drainage strategies in a salinity affected region. J Irrig Drain Eng 115(2):87-99 128(2)

Ghassemi F, Jakeman AJ, Nix HA (1995) Salinization of land and water resources. University of New South Wales Press, Sydney

Ghumman AR, Ghazaw YM, Niazi MF, Hashmi HN (2010) Impact assessment of subsurface drainage on waterlogged and saline lands. J Environ Monit Assess 172:189-197

Ghumman AR, Ghazaw YM, Hashmi HN, Kamal MA, Niazi MF (2012) Environmental and socio-economic impacts of pipe drainage in Pakistan. Environ Monit Assess 184:1671-1681

Goel A, Tiwari P (2013) Review of computer based software tools for salinity management in agricultural lands. J Indian Water Resour Soc 33(4):25-32

Gupta SK (2002) A century of subsurface drainage research in India. Irrig Drain Syst 16:69-84

Gupta SK (2003) A historical perspective of subsurface drainage research in India. Asian Agric Hist 7(1):45-54

Hanumanthaiah CV, Satyanarayana TV (2003) Cost effectiveness of subsurface drainage technology under Indian conditions-a boon to farming community in the areas of saline soils, paper no 118. Presented at the 9th international drainage workshop, Utrecht, The Netherlands

Hefny MM, Mohamed E, Metwali R, Mohamed AI (2013) Assessment of genetic diversity of sorghum (Sorghum bicolor L. Moench) genotypes under saline irrigation water based on some selection indices. Australian J Crop Sci (AJCS) 7(12):1935-1945

Hirekhan M, Gupta SK, Mishra KL (2007) Application of Wasim to assess performance of a subsurface drainage system under semiarid monsoon climate. J Agric Water Manag 88:224-234

Hornbuckle JW, Christen EW, Faulkner RD (2012) Analytical solution for drainflows from bilevel multiple-drain subsurface drainage systems. J Irrig Drain Eng 138:642-650

IPTRID SECRETARIAT (2007) Egypt's experience in irrigation and drainage research uptake, final report. Electronic Publishing Policy and Support Branch, Information Division, Food and Agriculture Organization, FAO, Viale delle Terme di Caracalla, 00153, Rome, Italy

Jaiswal SR, Dhruva Narayana VV (1972) Design of a sub-surface drainage system. In: Proceedings symposium on waterlogging causes and its prevention CBIP, vol 110(1), pp 91-100

Joint Completion Report on IDNP Result (2007) Recommendation on waterlogging and salinity control based on pilot area drainage research, p 90

Kahlown MA, Khan AD (2004) Tile drainage manual, Pakistan Council of Engineering in Water Resources (PCRWR), Islamabad, Pakistan, ISSB 969-8469-13-3, PCRWR Press, Islamabad

Kahlown MA, Marri MK, Azam M (2007) Design, construction and performance evaluation of small tile drainage systems in the Indus Basin. J Irrig Drain ICID 56(1):217-225

Kale S (2011) Field-evaluation of DRAINMOD-S for predicting soil and drainage water salinity under semiarid conditions in Turkey. Spanish J Agric Res 9(4):1142-1155

Kaledhonkar MJ, Gupta SK, Singh G.(2009) An overview of research, development, opportunities and challenges for subsurface drainage in India. In: 60th international executive council meeting \& 5th Asian regional conference, New Delhi, India

Kaledhonkar MJ, Kamra SK, Sharma DP (1998) Drainage measures for control of waterlogging in semi-arid regions. In: Proceedings 9th National Symposium on Hydrology, Amritsar, 26-27th Nov. Amritsar, pp 97-104

Kamble BM, Chougule BA, Rathod SD, Rathod PK (2006) Improvement of salt affected-water logged soils in western Maharashtra through subsurface drainage (Ssd) system. Asian J Biol Sci 1(2):64-67

Kamra SK, Singh SR, Rao KVGK, van Genuchten MTh (1991) A semi-discrete model for water and solute movement in tiledrained soils 1. Governing equations and solution. Water Resour Res 27:2439-2447

Kelleners TJ, Kamra SK, Jhorar RK (2000) Modeling of drainage water salinity of pipe drains. J Hydrol 234:249-263

Kolekar OL, Patil SB, Rathod SD (2014) Effects of different mole drain spacings on the yield of summer groundnut. Int J Res Eng Technol 3(4):2321-7308

Kornecki TS, Fouss JL, Grigg BC, Southwick LM (2001) Drainage research to improve runoff water quality and soil trafficability. Land Water Mag 45(3):10-13

Lal M (2011) Impact of subsurface drainage on land quality, ground water quality and crops yields in Haryana. $\mathrm{PhD}$, Thesis, National Institute of Technology Kurukshetra, Haryana, India

Lovas L (1972) Salinity control trials by sub-soil drainage at Digod. In: Proceedings All India symposium on soil salinity held at Kanpur, pp 156-160

Luthin JN (1978) Drainage Engineering. R. E. Krieger Publishing Co., Huntington 
Maity SP, Ghosh RK, Das NC, Patra SK (1996) Drainage and Crop Productivity in Saline Waterlogged Soil. AICRP on agricultural drainage. Bidhan Chandra Krishi Vishwavidyalaya. Kalyani, West Bengal, vol. 55, p 11

Mandal AK, Sharma RC (2011) Delineation and characterization of waterlogged salt affected soils in IGNP using remote sensing and GIS. J Indian Soc Remote Sens 39(1):39-50

Mathew EK, Nair M, Raju TD (1993) Drainage and Rice Productivity. AICRP on Agricultural Drainage. Kerala Agricultural University, Karumady, p 27

Michael AM (1967) Drainage research scheme. Annual report. College of Agricultural Engineering Punjab. Agricultural University, Ludhiana. p 108

Michael AM, Ojha TP (2013) Principles of Agricultural Engineering. Jain Brothers (New Delhi) 2(4):383-395

Naz BS, Ale S, Bowling LC (2009) Detecting subsurface drainage systems and estimating drain spacing in intensively managed agricultural landscapes. Agric Water Manag 96(4):627-637

Niazi MFK (2008) Evaluating the impact of subsurface drainage on land and water. Ph.D. thesis, University of Engineering and technology, Taxila, Pakistan

Nijland HJ, Croon FW, Ritzema HP (2005) Subsurface drainage practices: guidelines for the implementation, operation and maintenance of subsurface pipe drainage systems. ILRI Publication 60, Wageningen, p 607

Ozturk A (2004) Multi-objective drainage requirement of Harran Plain. Pak J Biol Sci 7(2):150-154

Pali AK, Katre P, Khalkho D (2014) An unsteady subsurface drainage equation incorporating variability of soil drainage properties. Water Resour Manag 28:2639-2653

Patel RM, Prasher SO, Bonnell RB, Broughton RS (2002) Development of comprehensive soil salinity index. J Irrig Drain Eng 128(3): 185-188

Qureshi AS, Iqbal M, Anwar NA, Aslam M, Ramzan MC (1997) Benefits of shallow drainage. In Proceedings of seminar on onfarm salinity, drainage, and reclamation. IWASRI Publication, p 179

Ramana RKV, Kishore R, Singh R (2009) Mole drainage to enhance soybean production in waterlogged Vertisols. J Agric Eng 46(4):54-58

Rao KVGK, Singh OP, Gupta RK, Kamra SK, Padey RS, KumbharePS, Abrol IP (1986) Drainage investigations for salinity control in Haryana. Bull. no. 10. CSSRI, Karnal, India. p 95

Ritzema H (2007) Performance assessment of subsurface drainage systems case studies from Egypt and Pakistan. Alterra-ILRI Wageningen University and Research Centre Wageningen The Netherlands, p 137

Ritzema PH (2009) Drain for gain, making water management worth its salt, subsurface drainage practices in irrigated agriculture in semi-arid and arid regions. Ph.D. Dissertation, Wageningen University and UNESCOIHE Institute for Water Education, Wageningen, The Netherlands

Ritzema HP, Satyanarayana TS, Raman S, Boonstra J (2008) Subsurface drainage to combat waterlogging and salinity in irrigated lands in India: lessons learned in farmers' fields. Agric Water Manag 95:179-189

Sarwar A (2000) A transient model approach to improve on-farm irrigation and drainage in semi-arid zones. Ph.D. Dissertation, Wageningen University \& Research Centre, The Netherlands

Sarwar A, Feddes RA (2000) Evaluation drainage design parameters for the fourth drainage project, Pakistan by using SWAP model: Part ii-modeling result. Irrig Drain Syst 14:281-299

Sarwar T, Muhammad N (2008) Effect of enhanced water allowance on the performance of tile drainage system at Shabaz Ghari pilot project area Swabi SCARP. Sarhad J. Agric 24(1):59-68

Satyanarayana TV, Lakshmi GV, Srinivasulu A, Hanumanthaiah CV, Ratnam M, Hemakumar HV (2002) Drainage and water management for salinity control in canal commands. A comprehensive report of research achievements of Bapatla Network Center, Indo-Dutch Network Operational Research Project, Acharya N.G. Ranga Agricultural University, Bapatla, India

Sethi M, Bundela DS, Sethi M, Lal K, Kamra SK (2010) Remote sensing and geographic information system for appraisal of saltaffected soils in India. J Environ Qual 39(1):5-15

Shakya SK, Gupta, PK Kumar D(1995) Innovative drainage techniques. AICRP on drainage. Punjab Agricultural University, Ludhiana, Punjab. p 34

Sharma RK, Yadav RD, Mourya BM, Kushwaha SS, Sharma AK (1995) Research on agricultural drainage in black soils of Barna command. AICRP on agricultural drainage. Jawaharlal Nehru Krishi Vishwavidyalaya, Powerkheda, Madhya Pradesh, India. p 35

Shekhawat RS (2007) Economic analysis of sub-surface drainage under Indira Gandhi Nahar Priyojna command area-A case study. Agric Econ Res Rev 20:361-374

Smedema LK(1990). Comparative study of the East Khairpur, Mardan and drainage-IV pipe drainage project. Project: PAK/ 83/022. Technical report no. 90/01, IWASRI Pub. No. 8, Lahore, Pakistan

Srinivasulu A, Satyanarayana TV, Kumar HVH (2005) Subsurface drainage in a pilot area in Nagarjuna Sagar right canal command, India. Irrig Drain Syst 19:61-70

Srinivasulu M, Rao AR, Babu MR, Babu GR, Kumar HVH (2014) Performance of subsurface drainage system installed at Appikatla region of Andhra Pradesh. Int J Argric Eng 7(1):180-185

Thatte CD, Kulkarni SA (2000) Status and strategy for prevention and reclamation of waterlogged and salt-affected lands from irrigated areas of India. 8th ICID international drainage workshop, New Delhi

Tiwari P (2011) Simulation of salt and water dynamics in subsurface drained land using hydrus. M.Tech. Dissertation, College of Agricultural Engineering, JNKVV Jabalpur, Madhya Pradesh India

Yadav JSP (1975) Annual Report. All India coordinated scheme for research on water management and salinity (unpublished)

Zimmer D, Bermond M, Melliand ML, Tato-Serrano S (2002) Global drainage status and needs, private communication, report will be published later by Cemagref/ICID 